\title{
Tempo-spatial variation of macrobenthic communities on a tidal flat of Wenzhou Bay, China
}

\author{
Variación espacio-temporal de las comunidades macrobentónicas en \\ el plano mareal de Wenzhou Bay, China
}

Bao-Ming Ge', ${ }^{1,2}$ Yi-Xin Bao ${ }^{2}$ and Hong-Yi Cheng ${ }^{2}$

\author{
${ }^{1}$ Jiangsu Provincial Key Laboratory of Coastal Wetland Bioresources and Environmental Protection, Yancheng Teachers \\ University, Yancheng, Jiangsu 224051 P. R, China. \\ ${ }^{2}$ Institute of Ecology, Zhejiang Normal University, Jinhua, Zhejiang 321004 P. R. China. baoyix@21cn.com
}

\begin{abstract}
The tempo-spatial variation of macrobenthic communities was studied on a tidal flat of Wenzhou Bay, China from November 2003 to August 2004. We collected 38 macrobenthic species belonging to 23 families, 8 classes and 7 phyla, most of which were arthropods and molluscs. Species richness, density and biodiversity significantly differed between tidal zones, seasons and the interaction between them. The tempo-spatial variations of the macrobenthic communities were also shown in cluster and ordination analysis. The middle tidal zone during autumn tends to have the highest values of the community descriptors. Thus, tidal zone and seasons have significant roles in structuring these communities.
\end{abstract}

Key words: Species distribution, tidal flat zones, Zhejiang Province

\section{INTRODUCTION}

The macrobenthos represents one of the most important permanent resident animal groups in coastal wetlands. Because of their sedentary life style, the distribution and abundance of benthos are particularly sensitive to local environmental conditions (Luckenbach et al. 1990), thus, this group is often used as an environmental indicator in environmental monitoring (Warwick et al. 2002, Ysebaert et al. 2002). The macrobenthos are important food resources, which partly explain the high reliance of wildlife on wetland habitats (Zwarts \& Wanink 1991, Warwick et al. 2002).

There are several factors determining the structure of macrobenthic communities, such as sediment, vegetation, temperature and salinity (Al Bakri et al. 1997a, b, Wu \& Shin 1997, Kaiser et al. 2001, Armonies \& Reise 2003). A number of studies demonstrated the existence of temporal variation for soft sediment benthic communities in temperate and subtropical regions (McCall 1977, Zajac \& Whitlatch 1982a, Lu \& Wu 2000), as well as in tropical regions (Lu 2005). However, no study has been carried out to determine tempo-spatial variations of macrobenthic communities at the Wenzhou Bay up until now.

Wenzhou Bay is the most important wintering and migration stop-over habitat for the endangered blackmouse gull (Larus saundersi) and black-faced egret
(Platalea minor) (Liu et al. 2001), with the macrobenthos being an major food resource (Cai et al. 2001). Studying the tempo-spatial variation of macrobenthic communities can thus help us to outline nature protection measures.

This study aims to quantify the macrobenthic communities at Tianhe flat (China) and determine the community structure, including its temporal and spatial variation.

\section{Materials AND METHODS}

All samples were taken from tidal flats at Tianhe flat

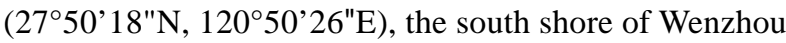
Bay, Zhejiang Province, China. The climate is sub-tropical; the tide type is informal semidiurnal tide with an average $4.5 \mathrm{~m}$ tidal range (Lu et al. 2005). The sediment is soft, most of its composition being silt. The average salinity of the seawater at the tidal flat is 30 psu.

Field sampling took place at the upper, higher, middle and lower tidal zones in November (autumn) 2003, February (winter), May (spring) and August (summer) 2004. Then 5 replicates were randomly spread throughout the middle of each tidal zone by using a $0.099 \mathrm{~m}^{2}(33 \mathrm{~cm} \times$ $30 \mathrm{~cm}$ ) stainless steel sampling box (depth of $20 \mathrm{~cm}$ ). In total, 80 samples were processed for quantitative 
analyses, and then additional qualitative samples were collected for species identification. Samples were washed through a $1.0 \mathrm{~mm}$ mesh sieve on the spot, and then fixed and preserved in neutral formalin-rose bengal mixture. Macrobenthic animals were stored, identified to the lowest possible taxonomic levels and counted. The species richness, density and biodiversity indices such as $R$ Margalef's species richness index, $H^{\prime}$ - Shannon's diversity index and $J$ - Pielou's evenness index were calculated for each sample as follows:

Margalef's species richness index (Margalef 1957):

$$
R=(\mathrm{S}-1) / \ln N
$$

Shannon’s diversity index (Shannon \& Weaver 1949):

$$
H^{\prime}=-\sum_{i=1}^{N} P_{i} \ln P_{i}
$$

Pielou's evenness index (Pielou 1966):

$$
J=\left(-\sum_{i=1}^{N} P_{i} \ln P_{i}\right) / \ln \mathrm{S}
$$

$P_{i}=$ proportion of individuals in the sample that belong to species $i$. $\mathrm{S}=$ total number of species (species richness) encountered. $N=$ the number of individuals.

Mean species richness, density and biodiversity indices were compared among seasons and zones by twoway ANOVAs (through a GLM). Then the data of 5 replicate samples were accumulated as a dataset, 16 datasets were used for multivariate analysis on communities. The Levene's test was used to determine equality of variance prior to using the GLM. When a dataset did not pass Levene's test the data was natural log transformed (Cleary et al. 2008), in the study, the datasets of abundance and $H^{\prime}$ of each sample were transformed.

For the multivariate analysis on the accumulated data sets of communities, the classification (Cluster Analysis) with the Euclidean distance similarity matrix method and ordination by non-metric Multi Dimensional Scaling (NMDS) were used to analyze community structure and species distribution based on accumulated abundance data with 4th root transformation (Heip et al. 1988, Olbers et al. 2009, Gogina et al. 2010). Clustering was carried out by a hierarchical, agglomerative method using average linkage; the results are displayed in dendrograms.

SPSS 16.0 (SPSS Inc.) and Microsoft Office Excel 2003 (Microsoft Inc.) were employed for statistical analysis.

\section{RESUlts AND DISCUSSION}

In total 38 species were recorded, belonging to 23 families, 8 classes and 7 phyla recorded in the qualitative investigation, most of them were arthropods (11 species), molluscs (15 species) and annelids (6 species) (Table 1).

There were significant differences in almost all community descriptors between zones, seasons and interaction; species richness [zones $\left(\mathrm{F}_{(3,64)}=61.89, P<\right.$ $0.001)$, seasons $\left(\mathrm{F}_{(3,64)}=35.82, P<0.001\right)$, zone $\times$ season interaction $\left(\mathrm{F}_{(9,64)}=15.53, P<0.001\right)$ ]; abundance [zones $\left(\mathrm{F}_{(3,64)}=63.88, P<0.001\right)$, seasons $\left(\mathrm{F}_{(3,64)}=44.71, P<\right.$ $0.001)$, and zone $\times$ season interaction $\left(\mathrm{F}_{(9,64)}=17.31, P<\right.$ $0.001)$ ]; $H^{\prime}$ [zones $\left(\mathrm{F}_{(3,64)}=36.08, P<0.001\right)$, seasons $\left(\mathrm{F}_{(3,}\right.$, $\left.{ }_{64)}=16.30, P<0.001\right)$, and zone $\times$ season interaction $\left(\mathrm{F}_{(9,}\right.$, $\left.\left.{ }_{64)}=8.11, P<0.001\right)\right]$; $R$ [zone $\left(\mathrm{F}_{(3,64)}=39.39, P<0.001\right)$, season $\left(\mathrm{F}_{(3,64)}=15.21, P<0.001\right)$, zone $\times$ season $\left(\mathrm{F}_{(9,64)}=\right.$ 6. 57, $P<0.001)$ ]; $J$ differed between zone only $\left(\mathrm{F}_{(3,64)}=\right.$ 43.358, $P<0.001$ ), but no difference was found between seasons $\left(\mathrm{F}_{(3,64)}=2.49, P=0.068\right)$ and zone $\times$ season interaction $\left(\mathrm{F}_{(9,64)}=0.95, P=0.486\right)$.

The analysis of the accumulated data sets of communities showed that the higher biodiversity/ abundance occurred in summer/autumn and the high/ middle zone, while lower biodiversity/abundance occurred in winter/spring and the upper/low tidal zone (Fig. 1).

In the cluster and ordination analysis, three community groups were classified by tidal zones; upper tidal (CG1), high-middle tidal (CG2) and middle-low zones (CG3) (Fig. $2 \mathrm{~A}, \mathrm{C}$ ). The results show a gradient indicating that the communities were changing among habitats. Three specie groups were then classified as within the non-low tidal zone with extensive species distribution (SG1), the nonupper tidal zone with extensive species distribution (SG2) and narrowly distributed species (SG3) (Fig. 2B, D), and the results showed that most of the species were distributed in two or three tidal zones (SG1 \& SG2), with a few species distributed in only one zone (SG3).

It has been reported that the community construction and biodiversity varied among seasons and tidal zones in some researches (Lui et al. 2002, Elliott et al. 2007, Tian et al. 2009). The abundances of molluscs were generally higher in winter and spring, those of crustaceans in autumn and summer. Temporal changes in macrobenthic community densities in predation pressure and the reproductive output of the animals were indicated by many studies (Ólafsson \& Persson 1986, Kneib 1992, Covi \& Kneib 1995, Sarda et al. 1998). Seasonal fluctuations in physical environmental parameters may also cause 
Table 1. Macrobenthic species found on the tidal flat of Tianhe, Wenzhou Bay, China. Code named species which were used in the quantitative analysis, which are ordered by abundance / Especies macrobentónicas encontradas en el plano mareal de Tianhe, Wenzhou Bay, China. Los códigos identifican las especies utilizadas en el análisis cuantitativo y ordenadas por su abundancia

\begin{tabular}{|c|c|c|c|c|}
\hline Phylum & Class & Family & Species & Code \\
\hline \multirow{11}{*}{ Mollusca } & \multirow[t]{8}{*}{ Gastropoda } & Assimineidae & Assiminea brevicula & $\mathrm{S} 1$ \\
\hline & & \multirow[t]{2}{*}{ Potamididae } & Cerithidea cingulata & S3 \\
\hline & & & C. largillierti & $\mathrm{S} 20$ \\
\hline & & \multirow[t]{2}{*}{ Littorinidae } & Littorina scabra & $\mathrm{S} 18$ \\
\hline & & & L. brevicula & S17 \\
\hline & & Stenothyridae & Stenothyra glabra & $\mathrm{S} 13$ \\
\hline & & Atyidae & Bullacta exarata & S4 \\
\hline & & Nassidae & Nassarius sp. & S5 \\
\hline & \multirow[t]{3}{*}{ Lamellibranchia } & Solenidae & Sinonovacula constricta & \\
\hline & & Corbulidae & Potamocorbula ustulata & S11 \\
\hline & & Tellinidae & Moerella iridescens & S9 \\
\hline \multirow[t]{15}{*}{ Arthropoda } & \multirow[t]{15}{*}{ Crustacea } & \multirow[t]{7}{*}{ Grapsidae } & Helice sheni & \\
\hline & & & H. wuana & $\mathrm{S} 12$ \\
\hline & & & Sesarma haematocheir & $\mathrm{S} 16$ \\
\hline & & & Eriocheir sinensis & $\mathrm{S} 28$ \\
\hline & & & Metaplax sheni & S24 \\
\hline & & & M. longipes & S25 \\
\hline & & & Macrophthalmus japonicus & S 23 \\
\hline & & \multirow[t]{3}{*}{ Ocypodidae } & Uca arcuata & $\mathrm{S} 14$ \\
\hline & & & U. lactea & \\
\hline & & & Ilyoplax sp. & S7 \\
\hline & & \multirow[t]{3}{*}{ Leucosiidae } & Philyra pisum & S27 \\
\hline & & & P. olivacea & $\mathrm{S} 15$ \\
\hline & & & P. carinata & $\mathrm{S} 21$ \\
\hline & & Alpheidae & Alpheus japonicus & \\
\hline & & Palaemonidae & Exopalaemon modestus & S26 \\
\hline \multirow[t]{6}{*}{ Annelida } & \multirow[t]{6}{*}{ Polychaeta } & Nephtyidae & Nephthys caeca & \\
\hline & & Glyceridae & Glycera chirori & \\
\hline & & Nereidae & Neanthes japonica & \\
\hline & & & Nereis japonica & $\mathrm{S} 2$ \\
\hline & & & Tylorrhynchus heterochaeta & \\
\hline & & Eunicea & Diopatra sp. & $\mathrm{S} 10$ \\
\hline Nemertina & & & Not identified & S8 \\
\hline Nematoda & & & Not identified & S6 \\
\hline \multirow[t]{3}{*}{ Chordata } & \multirow[t]{3}{*}{ Osteichthyes } & \multirow[t]{2}{*}{ Periphthalmidae } & Scartelaos viridis & S19 \\
\hline & & & Boleophthalmus pectinirostris & S22 \\
\hline & & Gobiidae & Rhinogobius sp. & \\
\hline Sipuncula & Phascolosomata & Phascolosomatidae & Phascolosoma esculenda & \\
\hline
\end{tabular}

temporal differences in species abundance (Odum \& Heald 1972, Daiber 1977, Lui et al. 2002).

The macrobenthic communities were affected by the tidal zone, seasonal change and the interaction between them on the tidal flat of Wenzhou Bay. The higher biodiversity occurred in the high and middle tidal zone, which was related to higher habitat complexity (Yuan et al. 2005), and habitat complexity was affected by environmental factors, such as vegetation, tide, grain size and the food web (Whitlatch 1977, Probert 1984, Ouisse et al. 2011). NMDS was used to analyze differences in the community structure of macrobenthic fauna in some similar studies (Clarke \& Warwick 1994, Lui et al. 2002, Steffens et al. 2006).The results of NMDS supported the cluster analysis, and also confirmed that the macrobenthic communities were significantly affected by tidal zone.

The seasonal change also can be described in this research. A significant difference was found among 

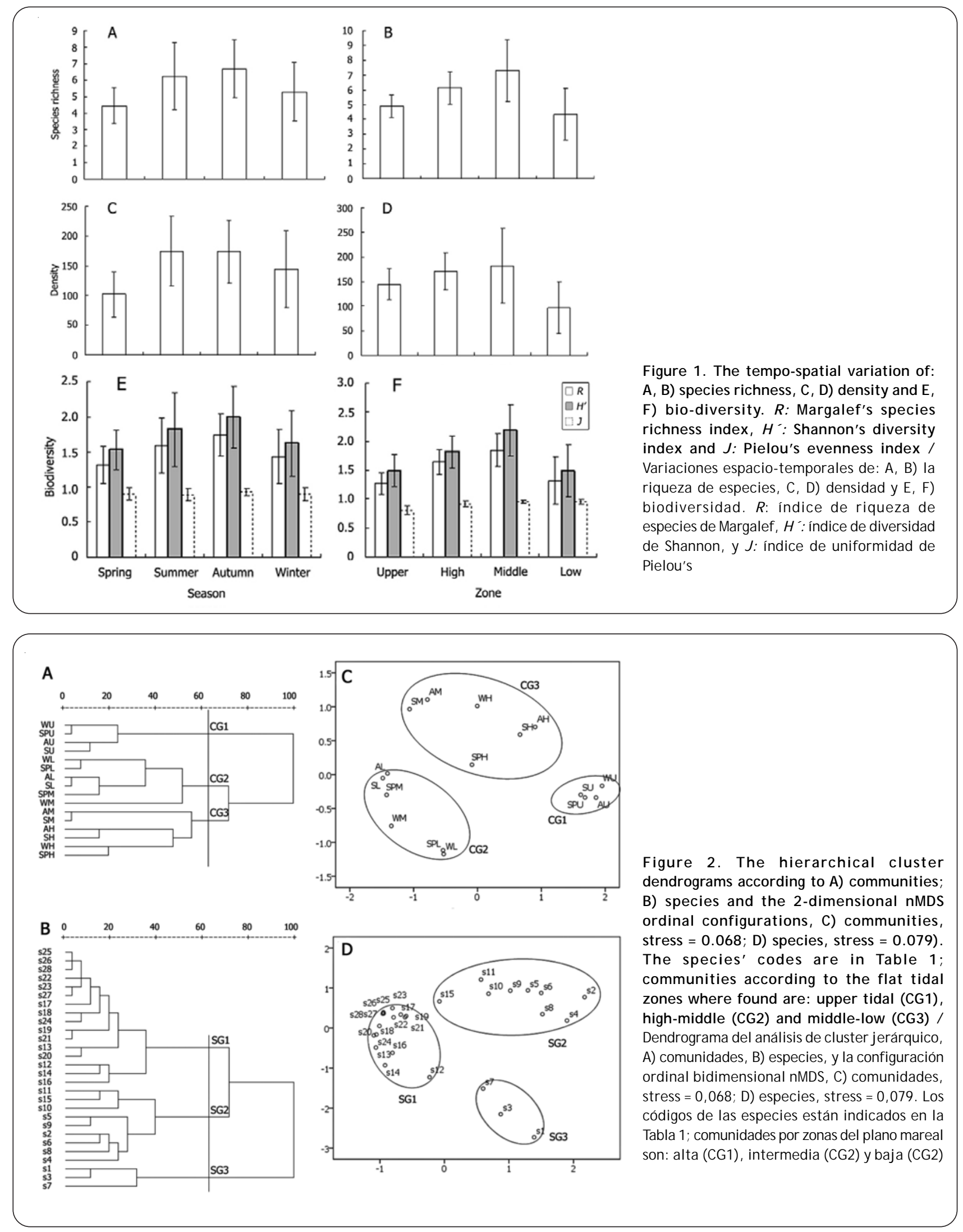
seasons, which was proved by some previous studies in temperate and subtropical regions, where some researchers found that the highest abundance and species richness were generally found in spring/summer, while the lowest values were found in autumn/winter (McCall 1977, Zajac \& Whitlatch 1982b, Lu \& Wu 2000). Different to this previous research, in this study the higher abundances and species richness were found in autumn/ summer, and the lower values were found in winter/spring.

The factor of season changes significantly affected macrobenthic community structuring in this research, but the relationship between a lower density and the impact of migratory birds in winter/spring should be considered cautiously in wildlife habitat management. The coast of southeast Asia is an important wintering and migration stop-over wetland for some kind of birds (Butler et al. 2001), resulting in the macrobenthos and birds to be both involved in a complex food web (Valiela et al. 2004), therefore the macrobenthos contribution to energy flow and especially to the diet of birds should be elucidated in the future (Ouisse et al. 2011). The effect of birds on macrobenthic communities should be investigated on the tidal flat of Wenzhou Bay.

\section{ACKNOWLEDGEMENTS}

We would like to thank Xiang Zheng for participating in the field work and Professor Yong-Pu Zhang for help with species taxonomy. We thank the referees for the advice and suggestions given in order to improve the paper. This research was supported by Zhejiang Provincial Natural Science Foundation of China (No. ZE0204).

\section{LITERATURE CITED}

Al Bakri D, M Behbehani \& A Khuraibet. 1997a. Quantitative assessment of the intertidal environment of Kuwait I: Integrated environment classification. Environmental Management 51: 321-332.

Al Bakri D, M Behbehani \& A Khuraibet. 1997b. Quantitative assessment of the intertidal environment of Kuwait II: Controlling factors. Environmental Management 51: 333-341.

Armonies W \& K Reise. 2003. Empty habitat in coastal sediments for populations of macrozoobenthos. Helgolander Marine Research 56: 279-287.

Butler RW, NC Davidson \& RI Guy Morrison. 2001. Globalscale shorebird distribution in relation to productivity of near shore ocean waters. Waterbirds 24: 224-232.

Cai L, J Lin \& $\mathbf{H}$ Li. 2001. Macroinfauna communities in an organic-rich mudflat at Shenzhen and Hong Kong, China. Bulletin of Marine Science 69: 1129-1138.
Clarke KB \& RM Warwick. 1994. Changes in marine communities: an approach to statistical analysis and interpretation. Natural Environment Research Council, Plymouth.

Cleary MB, E Pendall \& BE Ewers. 2008. Testing sagebrush allometric relationships across three fire chronosequences in Wyoming, USA. Journal of Arid Environments 72: 285301.

Covi MP \& RT Kneib. 1995. Intertidal distribution, population dynamics and production of the amphipod Uhlorchestia spartinophila in a Georgia, U.S.A. salt marsh. Marine Biology 121: 447-455.

Daiber FC. 1977. Salt-marsh animals: distributions related to tidal flooding, salinity and vegetation. In: Chapman VJ (ed). Wet Coastal Ecosystems, pp. 70-108. Elsevier, Amsterdam and New York.

Elliott M, D Burdon, KL Hemingway \& SE Apitz. 2007. Estuarine, coastal and marine ecosystem restoration: Confusing management and science - A revision of concepts. Estuarine Coastal and Shelf Science 74: 349-366.

Gogina M, M Glockzin \& ML Zettler. 2010. Distribution of benthic macrofaunal communities in the western Baltic Sea with regard to near-bottom environmental parameters. 1. Causal analysis. Journal of Marine Systems 79: 112-123.

Heip CHR, RM Warwick, MR Carr, PMJ Herman, R Huys, N Smol \& K Van Holsbeke. 1988. Analysis of community attributes of the benthic meiofauna of FrierfjordLangesundfjord. Marine Ecology Progress Series 46: 171180.

Kaiser MJ, G Broad \& SJ Hall. 2001. Disturbance of intertidal soft-sediment benthic communities by cockle hand raking. Journal of Sea Research 45: 119-130.

Kneib RT. 1992. Population dynamics of the tanaid Hargeria rapax (Crustacea: Peracarida) in a tidal marsh. Marine Biology 113: 437-445.

Liu AX, ZH Chen, P Ding, MJ Sun \& Q Du. 2001. Studies on the population number of waterfowls in Zhejiang Province. Journal of Zhejiang University (Agriculture and Life Sciences) 27: 325-329. [in Chinese with English abstract]

Lu L. 2005. Seasonal variation of macrobenthic infauna in the Johor Strait, Singapore. Aquatic Ecology 39: 107-111.

Lu L \& RSS Wu. 2000. An experimental study on recolonization and succession of marine macrobenthos in defaunated sediment. Marine Biology 136: 291-302.

Lu YJ, HL Li, HC Wang \& LQ Zuo. 2005. Back silting and regulation of waterway with sand bar in strong tidal estuary. Journal of Hydraulic Engineering 36: 1450-1456. [in Chinese with English abstract]

Luckenbach MW, RJ Diaz, EC Zobrist \& CH Hutton. 1990. Evaluation of the benthic resource value of impounded and non-impounded tidal creeks in Virginia, U.S.A. Ocean and Shoreline Management 14: 35-50. 
Lui TH, SY Lee \& Y Sadovy. 2002. Macrobenthos of a tidal impoundment at the Mai Po Marshes Nature Reserve, Hong Kong. Hydrobiologia 468: 193-212.

Margalef DR. 1957. Information theory in ecology. General Systematics 3: 36-71.

McCall PL. 1977. Community patterns and adaptive strategies of the infaunal benthos of Long Island Sound. Journal of Marine Research 35: 221-266.

Odum WE \& EJ Heald. 1972. Trophic analyses of an estuarine mangrove community. Bulletin of Marine Science 22: 671738.

Ólafsson EB \& LE Persson. 1986. Distribution, life cycle and demography in a brackish water population of the isopod Cyathura carinata (Kröyer)(Crustacea). Estuarine, Coastal and Shelf Science 23: 673-687.

Olbers JM, L Celliers \& MH Schleyer. 2009. Zonation of Benthic Communities on the Subtropical Aliwal Shoal, Durban, KwaZulu-Natal, South Africa. African Zoology 44: 8-23.

Ouisse V, P Riera, A Migné, C Leroux \& D Davoult. 2011. Freshwater seepages and ephemeral macroalgae proliferation in an intertidal bay: I Effect on benthic community structure and food web. Estuarine, Coastal and Shelf Science 91: 272-281.

Pielou ECJ. 1966. The measurement of diversity in different types of biological collections. Journal of theoretical biology 13: 131-144.

Probert PK. 1984. Disturbance, sediment stability, and trophic structure of soft-bottom communities. Journal of Marine Research 42: 893-921.

Sarda R, K Foreman, CE Werme \& I Valiela. 1998. The impact of epifaunal predation on the structure of macroinfaunal invertebrate communities of tidal salt marsh creeks. Estuarine, Coastal and Shelf Science 46: 657-669.

Shannon CE \& W Weaver. 1949. The mathematical theory of communication, 117 pp. University of Illinois Press, Urbana.

Steffens M, D Piepenburg \& MK Schmid. 2006. Distribution and structure of macrobenthic fauna in the eastern Laptev Sea in relation to environmental factors. Polar Biology 29: 837-848.
Tian YQ, JJ Wang, JA Duff, BL Howes \& A Evgenidou. 2009. Spatial patterns of macrobenthic communities in shallow-water tidal embayments and their association with environmental factors. Environmental Management 44: 119135.

Valiela I, D Rutecki \& S Fox. 2004. Salt marshes: biological controls of food webs in a diminishing environment. Journal of Experimental Marine Biology and Ecology 300: 131159.

Warwick RM, CM Ashman, AR Brown, KR Clarke, B Dowell, B Hart, RE Lewis, N Shillabeer, PJ Somerfield \& JF Tapp. 2002. Inter-annual changes in the biodiversity and community structure of the macrobenthos in Tees Bay and Tees estuary, UK, associated with local and regional environmental events. Marine Ecology Progress Series 234: 1-13.

Whitlatch RB. 1977. Seasonal changes in the community structure of the macrobenthos inhabting the intertidal sand and mud flats of Barnstable Harboe, Massachusetts. The Biological Bulletin 152: 275-294.

Wu RSS \& PKS Shin. 1997. Sediment characteristics and colonization of soft-bottom benthos: a field manipulation experiment. Marine Biology 128: 475-487.

Yuan X, H Liu \& J Lu. 2005. Effect of Scirpus mariqueter vegetation on salt marsh benthic macrofaunal community of the Changjiang estuary. Journal of Coastal Research 21: 73-78.

Ysebaert T, P Meire, PML Herman \& H Verbeek. 2002. Macrobenthic species response surfaces along estuarine gradients: prediction by logistic regression. Marine Ecology Progress Series 225: 79-95.

Zajac RN \& RB Whitlatch. 1982a. Responses of estuarine infauna to disturbance. I. Spatial and temporal variation of initial recolonization. Marine Ecology Progress Series 10: $1-14$.

Zajac RN \& RB Whitlatch. 1982b. Responses of estuarine infauna to disturbance. II. Spatial and temporal variation of succession. Marine Ecology Progress Series 10: 15-27.

Zwarts L \& JH Wanink. 1991. The macrobenthos fraction accessible to waders may represent marginal prey. Oecologia 87: 581-587. 